\title{
Religion and Ethnicity: Muslim Turkish and Tatar Identity in Dobruja (Romania) throughout the 20th Century ${ }^{*}$
}

\author{
Din ve Etnik: 20. Yüzyıl Boyunca Dobruca (Romanya)'da Müslüman, \\ Türk ve Tatar Kimliği
}

Adriana CUPCEA ${ }^{* *}$

\begin{abstract}
In my study I approached Turkish and Tatar communities in Dobruja (Romania) in the context of the ethnic and religious diversity in the Balkans, which Maria Todorova considers to be as the only continuous traces of a common continuous Ottoman heritage. Using the field research and documentary research, I tried to identify the political, economic, cultural and social factors that have determined the evolution of the collective mentality of the Muslim Turks and Tatars in Dobruja from perceiving themselves as a religious community to a self-perception as ethnic community throughout the 20th Century. Finally, I tried to identify the present overlays between the two hypostases (religious and ethnic) in the collective imaginary of the Turkish and Tatar Muslims in Dobruja.
\end{abstract}

Keywords: Turks, Tatars, Dobruja (Romania), Religion, Ethnicity.

Öz

Bu çalışmada Dobruca'daki (Romanya) Türk ve Tatar topluluklarına, Maria Todorova’nın Balkanlardaki ortak Osmanlı mirasının süreklilik arzeden yegane izleri olarak dikkate aldığı etnik ve dinsel çeşitlilik bağlamında yaklaşılmıştır. Saha çalışması ve belgelere dayalı araştırma kullanılarak 20. yüzyıl boyunca Dobruca'daki Müslüman Türk ve Tatar kollektif zihniyetinin, kendilerini bir dini topluluk olarak algılamaktan, etnik topluluklar olarak algılamaya doğru evriminde belirleyici olan siyasal, ekonomik, kültürel ve sosyal faktörler tespit edilmeye çalışılmıştır. Son olarak Dobruca’daki Türk ve Tatar Müslümanların ortak imgesindeki iki hipotez (dini ve etnik) arasında kalan mevcut katmanlar tespit edilmeye çalışılmıştır.

Anahtar Kelimeler: Türkler, Tatarlar, Dobruja (Romanya), Din, Etnik.

* $\quad$ Bu makale Marmara BAPKO projesi kapsamında SOS-L-080715-0354 numaralı L tipi proje desteği ile hazırlanmıştır.

** PhD Researcher, The Romanian Institute for Research on National Minorities, Cluj Napoca, Romania. 


\section{Introduction}

My approach is following the assertion of Maria Todorova that in all fields (cultural, social and economic), except the demography and folklore, the break with the Ottoman heritage as a continuity occurred immediately after the independence of the Balkan states and was completed at the end of WWI. The conclusion of Todorova is that in fact the most important part of the Ottoman heritage can be detected in the demographical field and only the ethnic and religious diversity can actually be considered as traces of a common continuous heritage (Todorova, 2004: 12-13).

Thus, in my study I approached Turkish and Tatar communities in Dobruja (Romania) as part of this specificity of the Balkans. Using the field research (semi structured interviews, life histories, participant observation)and the discourse analysis and documentary research, I tried to identify the political, economic, cultural and social factors that have determined the evolution of the collective mentality of the Muslim Turks and Tatars in Dobruja, from perceiving themselves as a religious community to the present self-perception as ethnic communities, throughout the 20th Century,. Finally I tried to identify the present overlays between the two hypostasis (religious and ethnic) in the collective imaginary of the Turkish and Tatar Muslims in Dobruja.

\section{Elements inherited from the Ottoman period: case of Muslim minorities in the Balkans}

To understand the Turk and Tatar collective representations and the way the others saw them officially or socially, one needs to understand the millet system introduced by the Ottomans first. This particular form of social organization was based on the faith affiliations of the various populations making up the Empire, with the millets being religion-based communities, administered by a religious hierarchy to a great extent autonomous in terms

of religious life and education and legal arrangements. This system favored a religious belonging over ethnic belonging (Merdjanova, 2013: 2) and the definitions and selfdefinitions as religious community reflect the survival of Ottoman administrative and mental patterns within the new nation-states created on the territories of the former Ottoman Empire. This is implicitly the case of Dobruja which became part of Romania in the post-Ottoman era.

Authors such as Ina Merdjanova or Nathalie Clayer maintain that the heritage of the millet system was visible in these new states both as the maintaining of faith-based collective identities (Clayer, 2004/2005: 14) and the new states' national policies for their own Muslim minorities, i.e. they are dealt with as separate quasi-autonomous entities in the new social and political contexts. Merdjanova introduces the post-Ottoman concept of the quasi-millet (Merdjanova, 2013: 3) to define the status of the Muslim minorities in the new Balkan nation-states established on the former Ottoman territories. 


\section{I.I. The Case of Turks and Tatars in Dobruja}

The secular concept of citizenship imposed on the new nation-states by the powerful states under the 1878 Treaty of Berlin ${ }^{1}$ meant for the Muslims living within the borders of the new states that their rights of residence and of ownership as well as their religious freedom were guaranteed (Merdjanova, 2013: 10). The notion of guaranteeing equal citizenship for Muslims was often met with opposition and this was the case for Romania, too. After the 1878 incorporation of Northern Dobruja in Romania, the province was subject to a different extraconstitutional administrative regime that lasted until 1913. Due to this special status, the people living in the province enjoyed a local version of citizenship which denied them political participation and representation and prevented them from owning property outside the province (Iordachi, 2002: 167-197). ${ }^{2}$ As a religious minority sensu stricto, the Muslims had formally enjoyed a large degree of religious autonomy although it was more a case of alternating autonomy and state

1 The treaty signed after the Conference of Berlin recognized the de jure independence of Romania, Serbia and Montenegro.

2 In his work Citizenship, Nation and State-Building: The Integration of Northern Dobrogea into Romania (18781913), The Carl Beck Papers in Russian\&East European Studies, no. 1607, 2002, the historian Constantin Iordachi discusses based on primary sources the domestic politics regarding the region of Dobruja, after becoming part of the Romanian state in 1878. He discusses the adoption by the Romanian Parliament, in March 1880, of the Law Concerning Dobruja's Administrative Organization. He stresses the next issues: the Article 3 which stated that all the inhabitants of Dobruja, who on April 11, 1877, were Ottoman citizens were becoming Romanian citizens; Article 5 stipulated that inhabitants of Dobruja who became Romanian citizens were equal before the law, enjoying all civic rights, and being able to be appointed in public functions, regardless of their origin or religion, while article 6 extended to the inhabitants of Dobruja numerous civic rights provided by the Constitution. The law also guaranteeed free education, liberty of conscience and religious belief, and stipulated the military recruitment of Dobrujans into the Romanian army. In this way, the 1880 law implemented a specific type of citizenship in Dobruja, providing for equality before the law and guaranteeing certain civil rights and liberties. Although Dobruja was formally incorporated into Romania, the 1880 law was conceived as Dobruja Constitution and formed the basis of a separate, exceptional administrative regime in the province. This meant that, although nominally Romanian citizens, the Dobrujans had no political rights: article 4 stipulated that a special law will determine the conditions under which Dobrujans will be able to exercise their political rights and buy real estate in Romania proper. Another law stipulated their representation in the Romanian Parliament. Furthermore, civil liberties were potentially restricted by article 6 , which stated that the government, though a decree by the Council of Ministers can forbid every demonstration that is dangerous to public order. Laws on the political emancipation of Dobrujans announced in article 4 were passed gradually only in 1908-1913. From 1878 to 1908, the inhabitants of Dobruja thus enjoyed only a local type of citizenship. They were denied political representation in parliament and the right to enroll in political parties; instead, once a year, two representatives of the province would raise issues of specific Dobrujan interest to the prince. In addition, once they crossed the Dabube into Romania, they were treated as virtual foreigners and were denied the right to participate in politics or to acquire real estate (Iordachi 2002: 24).

Regardind the property legislation, in April 1882 the Immovable Property Law of Dobruja was adopted. The aim of this law was the transformation of the Ottoman conditional ownership of agricultural land into capitalist property. The condition peasants had to fulfil in order to become owners was financial compensation paid to the state, and those peasants who did not fulfil their financial obligations were dispossessed by the state (Iordachi 2002: 28). Between 1889 and 1914, 82,127 hectares were redistributed to Romanian colonists in the province (Ioradchi 2002: 31,32 ). The colonization process triggered changes in the ethnic makeup of the province and at the same time had an impact on the land ownership model in the province. More precisely, in 1882 Dobruja had 175,075 hectares of arable land. Turks and Tatars were the community who owned most land in the province, i.e. $50 \%$ of the arable land, followed by Romanians and Bulgarians, each of these ethnic groups owning about $23 \%$ of the arable land. This distribution was radically modified by the colonization process. In 1905, Romanians were the main land owners, with $63 \%$ of the arable land, while the proportion owned by Turks and Tatars fell to 7\% (Iordachi, 2002: 39). 
interference in practice. Specifically, they had spiritual and administrative autonomy - like other Muslim communities in the Balkans - under the formal jurisdiction of the Seyhülislam ${ }^{3}$ in Istanbul. ${ }^{4}$ The 1880 Law Concerning Dobrogea's Administrative Organization granted important minority rights to Muslims: it provided state salaries for the Muslim personnel of mosques, instituted a state-sponsored Muslim seminar in Babadag, established separate civil and juridical institutions for Muslims and provided for their conscription in separate military regiments with traditional Muslim uniforms and food customs (Iordachi 2002: 38). In 1923 the new Turkish Republic is established under the rule of Mustafa Kemal Atatürk, followed by the abolition of the Caliphate in 1924, a context in which the Şeyhülislam no longer applies. Parallel to that, Dobruja Muslims had, as we already said, their own institutions, hierarchies and administrative structures although they depended financially on the Romanian state. ${ }^{5}$ Merdjanova and Köksal among others note that the mechanism used to govern the Muslims living in the new Balkan states confirms the tendency of states resulting from the partitioning of multi-ethnic empires to integrate the old administrative practices into the new structures (Merdjanova, 2013: 11; Köksal, 2006: 501-21). These developments combined with the inherited millet mentality explain the faith-based identities and self-identities of Dobruja Turks and Tatars at the beginning of the 20th century.

In his 1986 paper, French scholar Alexandre Popovic indirectly makes the same assertion as a characteristic of inter-war Dobruja Muslim community and emphasizes the persistence of faith-based organizations in the inter-war local administration (Popovic, 1986: 242). Along the same lines, Nuredin Ibram notes that in the areas with a dense Muslim population up until WWII, the Muslim community had its own traditional organizations in place and it still has them to this day. ${ }^{6}$ Namely, the territorial Muslim community was organized and run according to its own rules approved by Muslim followers with its own council elected for a fixed term (Ibram, 2009: 134).

3 Şeyhülislam was the highest position in the Ottoman religious hierarchy (ulema) and it governed the empire's religious affairs.

4 In pratice that was not the case. For example after 1878, when the Austro-Hungarian Empire replaced the Ottoman Empire in Bosnia and Herzegovina, was established a Muslim religious authority hierarchy including a head (reisululema) and a committee of four religious scholars (ulama-i Mejlis), both being only accountable to Vienna either before the Şeyhülislam in Istanbul (Adanir, Farooqi 2002: 270).

5 There were two muftiates between 1878-1913, one in Tulcea and one in Constanța, independent from each other but with equal status. As late as 1935, there were four kadiates (religious tribunals) and they ruled on civil law issues for the Muslim population. All the muftis and kadis received wages from the Romanian state and the kadis were appointed by the Ministry of Internal Affairs and were government employees. The muftis were appointed by the ruling political party. Before the dissolution of the Caliphate in 1924, the spiritual legitimacy of the mufti was derived from the Şeyhülislam in Istanbul and the legality of the position was obtained either via the Ottoman ambassador in Bucharest or via the consul in Constanța who confirmed the mufti appointed by the Romanian government on behalf of the Şeyhülislam. See de Jong 1986: 176; Popovic 1986: 204-207.

6 The main pillar of the Muslim faith before WWII was and still is to this present day the religious community comprising all of the Muslim followers in one settlement, led by a committee made up of 5, 7 or 9 members elected for a 3 or 4 -year term (currently the committee is made up of 5 to 7 members elected for a 4 -year term). See Ibram 1998: 134; Dulciu 2009: 397. 


\section{External ideological influences on the Turks and Tatars in Dobruja at the beginning of the XXth Century}

Merdjanova claims that there was a tight link between the construction of Muslim identities in the former Ottoman territories and their representative institutions. Thus, while originally these were Islamic religious institutions, they later developed into various types of cultural, educational and political entities independent of the religious establishments. She speaks of a process of nationalization of Balkan Muslims (Merdjanova, 2013:11), possibly the ethnicizing of the Dobruja Muslims, undertook in the context of the modernization and secularization of the Muslim society.

Keeping in mind Merdjanova's assertion and coming back to my original statement that, up until WWI, religion defined the way the two communities were perceived as the religious identity was stronger than the ethnic one (Omer, 2014: 247-8), there is another crucial factor - apart from the Ottoman socio-mental and administrative surviving features - that marked the development of the identity of Dobruja Turks and Tatars, i.e. the connection to and the influence of external political and social movements. Some of them originated from the Ottoman Empire and later on from its successor state structure, the Republic of Turkey, established in 1923 by Mustafa Kemal Atatürk, and others from Crimea, the Tatars place of origin (de Jong, 1986: 177). These influences, as we shall see, will determine a reconfiguration of the identity make-up, leading to the creation of a sense of ethnic belonging.

Before the 1924 dissolution of the Caliphate, the religious component dominated the way the Dobruja Muslim community was perceived and perceived itself, and this was supported - as I already described - by the persistence of the millet mentality and the symbolic belonging to the Şeyhülislam in Istanbul. The Ottoman Empire, later on Turkey, was perceived and perceived itself as the protective mother-state of all Balkan Muslims, Dobruja Muslims included, even after the establishing of the republic in 1923 - Turkey's support being however directed mainly at the Turk populations in the area beyond this point in history (Merdjanova, 2013: 51), in line with the ethnic nationalism promoted by Mustafa Kemal Atatürk. Hugh Poulton deems the inherited millet mentality, more precisely the sense of shared belonging to the Islamic religion, essential to both the post-Ottoman self-identity building process and to the identification - selfidentification included - of the Ottoman Empire and later on of Turkey as mother-state ${ }^{7}$ for all Balkan Muslims (Poulton, 1997: 200).

The centrality of the religious - translated as the religious community approach to identity - is supported by the phenomenon of Muslim migration out of the Balkans, which became intensified after their integration in the Christian states newly formed on the former Ottoman territories. Interwar emigration was part of a wider process of Balkan Muslim migration to Ottoman territories as a result of the Balkan states policies towards Muslim populations. The colonization and nationalizing

7 Further I use the notions of mother-state and homeland as defined in the acceptation of Rogers Brubakers as an external national state to which the national minorities belong, or can be contructed as belonging, by ethnocultural affinity, though not by legal citizenship (Brubaker 1995:108). 
policies of new states and the launching of a process of farm land redistribution were among the chief reasons for the migration outflow of Balkan Muslims first to the Ottoman territories and post1923 to Turkey. ${ }^{8}$ The Dobruja Muslim Turks and Tatars were no exception to this phenomenon. In a report by government authorities, we have found the main causes of out-migration: insufficient farm land property following the land reform as rural Turks and Tatars had less and less land, their title deeds were checked, new high taxes were set which they could not afford to pay; the actions of the Bulgarian bourgeoisie; the hard living conditions due to lack of water, abuse by the gendarmes and local administrations who used the Turkish population for various purposes; the impoverishment of the communities; and not least the fact that some Turks with valid title deeds were excluded from the land reform (Ekrem, 1994: 128). Citing a Turkish source on early 20th-century emigration from Romania and Bulgaria to Turkey, Brian Glyn Williams asserts that in the memory of the émigré generations their emigration to the Ottoman territories is framed in religious terms as hijra, i.e. the migration out of the lands of the unfaithful and into the lands of Islam (Williams, 2001: 111, 244). Ak toprak, the term used to refer to the Ottoman territory and later on Turkey, still in use in the discourse of remembering the migration of previous generations, is laden with religious symbolism and it literally means "white land", i.e. the blessed lands of Islam of the Ottoman Empire (Williams, 2001: 129, 336). In his analysis of the Crimean Tatar emigration from Dobruja, Williams furthers this idea citing Müstecep Ülküsal who says in his 1940 book Dobruca ve Türkler that the Dobruja Muslim hodjas claimed that it was the Muslims' duty to quit the lands of the unfaithful just as it was the Turks' (in Turkey) duty to help them reach ak toprak (Williams, 2001: 243). Williams says that the origin of this perception of the Ottoman territories dates back to the Crimean Tatar migrations following the 1856 Crimean War, when a large number of Crimean Tatars resettled in Ottoman Dobruja. He also emphasizes that their long history under Ottoman rule played an important role in establishing a sense of historic, ethnic and religious continuity between the Tatars and the territories of the Muslim Turks (Williams, 2001: 129). This explains why, after the collapse of the Ottoman Empire, and given that their homeland (Crimea) was under Russian rule, Dobruja Tatars became convinced that Turkey was their devlet baba, their father state (Williams, 2001: 280) or the Tatars' protective state.

Therefore It was only natural that the political configuration and identity building of the Turks and the Tatars were influenced by political and ideological driving forces from their homeland territories. First, the late Ottoman brand of Turkish nationalism, typical of the Young Turks movement, was diffused in the Dobruja community by followers of the movement who came to Dobruja from the Ottoman Empire such as Ibrahim Temo, head of the Dobruja and Bulgarian Young Turks organization (Hanioğlu, 2001:152-154). In their many newspaper articles published in Dobruja (Ekrem, 1994: 139-141) (Omer 2013: 257), they promoted the Western ideological elements typical of the Young Turks' movement, ${ }^{9}$ as well as constitutionalism or the imperative

8 For more details on the colonization and nationalizing policies of the Balkan states at the beginning of the 20th Century and their effects on the migration phenomenon towards Turkey see Özgür Baklacıoğlu 2015: 49, 50 and Jovanovič 2015: 87-103.

9 The rise of national movements within the empire, starting with the end of the 20th century and threatening its territorial integrity, led to the emergence of a Turkish nationalism whose aims were the abolition of the sultan's 
role of education in societal progress (Ekrem, 1994: 142-143), which in time led to the shaping of a new sense of self for Dobruja Muslims. Following the dissolution of the Ottoman Empire and the creation of the Republic of Turkey in 1923, the sense of belonging to the Empire became parallel to the embracing of Turkey as successor of the former empire despite Mustafa Kemal Atatürk's newly implemented secular reformism. Turkey became the space of reference for both Turks and Tatars, given their historical, cultural and religious affinities, and functioned as an essential identity element - the sense of belonging to the Turkic world replaced the sense of Muslim solidarity, the prevailing form of identity in the Ottoman Empire. Notwithstanding the initial resistance to Mustafa Kemal's modernization and secularization actions, the Dobruja Muslim society gradually opened up empathically and instinctively to these influences coming from Turkey, the homeland of the Turks and the protective state of the Tatars.

We find the same phenomenon in the specific case of Dobruja Tatars and their relation to homeland, Crimea. As the Crimean Tatar intellectual elite started identifying with the nation of Tatar Crimea after 1906, a large proportion of the Dobruja Tatar intellectuals developed a sense of territorial belonging to Crimea (Williams, 2001: 436). At the end of the 19th century, the Dobruja distribution of the newspaper designed and published by the great Tatar thinker Ismail Gaspiralı provides the entry point for certain reform ideas (Omer, 2013: 248) such as the unity of the Turkic nation with its modern meaning, ethnolinguistic content (Kırıml1, 1996: 117), education-based modernization and the new learning method (usulu cedid) ${ }^{10}$ associated with the secularization of learning (Fisher, 1978: 102). The calls for secular reforms and national unity and later the programs of the Young Turks and even later those of the Young Tatars had a decisive effect on some sections of the Dobruja Tatar population, changing the focus of their identity from the traditional religious community approach to the ethnic community approach, the latter marked by a sense of national identity and strong attachment to their homeland Crimea, defined in modern Western terms. At the turn of the 20th century, a national movement took shape in Dobruja, attuned to similar developments among the Tatars in Crimea. From Ismail Gaspiralı,

arbitrary absolutism, the modernization of the empire and bringing it to the same level of development of Europe, as well as adopting a constitution which would stipulate the equality of all minorities of the empire and hopefully would lead to the demise of separatisms. Starting with 1980, this nationalist movement will be called the Young Turks, with a social basis made up of intellectuals, army officers and the bourgeoisie, all of them beneficiaries of the spill-over of Western ideas and material culture. In 1902, following a division within the movement, a new Committee of Union and Progress is formed and the focus shifts to Ottoman nationalism. In 1908, they organize a coup and they come to power; a parliament is elected and a thirty-year old constitution is revived, stipulating the right to learn and publish in their native languages for all the empire's populations. Although the Young Turks' revolution was meant to save the unity of the empire, ever since its first defeats (the annexation of Bosnia and Herzegovina by Austria, the Bulgarian Declaration of Independence in 1908), Ottoman ideology showed signs of weakening. The Young Turks gradually gave up the notion of brotherly coexistence of all the empire's peoples and turned to exulting the Turkish nation. This tendency will only grow stronger after the Balkan wars (1912-1918) which cost the Ottoman Empire almost all of its European territories. At this time, the liberal feeling starts to disappear from Ottoman political and cultural life and one by one the ethnic associations are closed down. The Young Turks made of Turkish nationalism their distinctive brand, aspiring to create a Turan Empire which would span from Europe to Central Asia. See Mantran 2001: 502, 503.

10 For details on Ismail Gaspiralı's proposal for an education reform known as the New Method (unsulu cedid), see Kırımlı 1996: 45-47. 
going through the Young Tatars movement created after the defeat of the Russian revolution in 1905, and up until 1908, the Crimean Tatar national movement completed the process of defining the main features of modern Tatar nationhood: the definitive mapping of the notion of a Crimean Tatar nation on the territory of Crimea, a compact and bounded geographical entity, easily identifiable from the outside. The shared language, albeit spoken in several dialects, the shared practice of the Muslim faith, an emphasis on the historical precedent of statehood, i.e. the Crimean Khanate, led by the Tatars' forebears, located on the territory acknowledged as the homeland, along with the claim of belonging to the cultural and historical heritage of the Turkic and Muslim world (Kırıml, 1996: 221), they all constituted further arguments in favor of a Tatar national distinctivism embraced by the Crimean Tatar intellectuals.

The movement's center of command was in Istanbul and consisted of the Crimean Tatar leaders who took refuge there; the Tatar leaders in Turkey, Crimea and Dobruja were in permanent contact. The main channels of distribution for these national ideas were the actual meetings of these leaders, in one of the three locations, open conferences, the publication of newspapers or magazines printed in Istanbul, e.g. Çolpan (The Morning Star), Teșvik (The Impetus) and Dobruca Sadası (The Voice of Dobruja), which also made their way into Dobruja (OberländerTârnoveanu, Adam, 2005: 50-1).

The historian Mehmet Ali Ekrem describes the organizational, social and mental expressions of the influences of the secularization and modernization processes coming from the two homeland territories, i.e. Turkey and Crimea. Still following Merdjanova (2013), I maintain that the construction of Muslim identities in the states created on the former territories of the Ottoman Empire was tightly linked to their representative institutions and, as Merdjanova underlines, to new secular institutions, independent of the religious ones that emerge as a consequence of secularization and modernization. Merdjanova takes these institutions to be an indicator of the nationalization or possibly the ethnicization of identity. Therefore, starting with the 1910s and up to WWII, we witness the emergence of general but also of local cultural and educational organizations in Dobruja, e.g. The General Education Society of Dobruja (1909), The Association of Muslim Seminar Graduates (1911), The Mehmet Nyiazi Cultural Association (1938) (Ekrem, 1994: 155,156), The Circle of the Young Turks (Omer, 2014: 254) whose main objectives, i.e. editing publications, organizing scientific and cultural conferences in Dobruja villages and towns, supporting literacy, especially for young people, raising awareness about the population's rights in the newly-formed state, show a strong societal tendency towards secularization and modernization. Not least, there is the Emel Mecmuasi group who, in addition to their focus on Turkey, focused on the Crimean Tatar situation and put a special emphasis on the events organized by various associations to promote the Tatar national movement (Omer, 2014: 254).

In the 1930s, the way the students at the Medgidia Muslim Seminar dress changes as the medieval Ottoman costume and the fez are replaced by the cap and the European suit. ${ }^{11}$ The seminars and

11 After 1923, a number of laws limited more and more the use of traditional clothing items. First to adopt the hat were the civil servants, educated people generally, and then came the 1934 reform law enforcing control over clothing 
all the elementary schools in Dobruja adopted the Latin alphabet at the same time as Turkey did. With an arrangement between the Romanian and the Turkish ministry,Turkey would send text books to Romania. Ekrem notes a visible tendency towards modernization, clothing included, among the majority of the Turk and Tatar population, but he also points out the warnings present in many Turkish-speaking publications at the time concerning a so-called attachment to the past, particularly in the field of theological and Turkish language education and the large number of illiterate Turks and Tatars (Ekrem, 1994: 153).

In general, we can safely say that one salient characteristic of the evolution of the Muslim Turks and Tatars in the early 20th century was the shift from an identity exclusively based on their belonging to Islam to one that featured an important ethnic content (Poulton, 2000: 48), understood as the coexistence of a religious identity component and a new ethnic identity mainly shaped by external political and ideological factors.

This process was cut short by the coming to power of the communist regime in 1946 and the isolation that ensued, including the cutting off of ties with the homeland territories, particularly Turkey which was a capitalist state and a NATO member and, therefore, a representative of the Western bloc. These developments left a deep mark on the Turk and Tatar society and led to deep social, economic and identity transformations in the Romanian society as a whole, the direct consequences of the processes associated typically with the building of a socialist society, such as secularization, industrialization, collectivization, urbanization or rural to urban migration, and, not least, the social homogenization of all citizens regardless of their nationality (Florea, 1975: 82, 83).

\section{The communist period}

Nathalie Clayer (2004/5) mentions a few consequences of the policies implemented by various communist regimes on Muslim communities in the Balkans, which are also valid for the Dobruja community. These are the emergence of new secular, intellectual and technical elites, the weakening of the religious institutions and practice, and implicitly a changed attitude towards religion (Clayer, 2004/5: 20), namely the individualization of belief which becomes confined to the private space and is associated with the older generations.

At first, between 1950-1960, inclusion in the Romanian communist society was driven by policies meant to eliminate all political rivals, to achieve isolation from Turkey and the international Muslim community, ${ }^{12}$ to stifle religious life indirectly, while pretending to grant cultural rights to the minorities. In 1948 and 1956-1957, Turkish-language education survived but was affected by a sharp decrease

items, which forbid clothes tailored according to religious canons, e.g. the veil or the turban, and which actively promoted the use of Western clothes. The Hat Law introduced the use of Western hats to the detriment of the fez.

12 In the 70s and 80s, the Muslim community was used by the communist regime to cultivate its relations with the Arab Muslim states. In 1973, for instance, the Romanian communist state allowed a group of Muslims to go on a pilgrimage to Mecca, with Libyan financial support. For similar propagandistic reasons, in 1980 a magazine of the Muftiate, The Muslim Faith Magazine (Revista Cultului Musulman), was published and it praised the prosperity and the rights that the Romanian Muslim community supposedly enjoyed. See Jong 1986: 181-182. 
in the number of schools and teaching staff. For a while after the 1948 education reform, there was a division of Dobruja schools into Turkish and Tatar schools as the authorities experimented with the introduction of the Tatar dialect imported from the Tatar Autonomous Soviet Socialist Republic in Kazan, the USSR, along with text books and literature books (Ibram, 1998: 178). The introduction of the Tatar language was meant as an opposition to the Turkish language perceived by the communist regime as the official language of a capitalist state. Therefore, an attempt was made to thwart the influences of the Turkish intelligentsia or at least of attitudes coming from a capitalist country. These were purely propagandistic actions, lacking any practical purpose or positive effects for the promoting of the Tatar language and culture, and this process of incentivizing the Tatar language ended in the late 1960s. Beginning with the 1956-1957 academic year, all Turkish-language religious and secular education institutions were closed (Ibram, 1998: 173).

According to the surveys conducted in this period, both groups and individuals show a blurring of their sense of ethnic belonging caused and motivated by the new elite's preoccupation to adapt socially and professionally to the communist society. ${ }^{13}$ For those families who become the target of the authorities' repression, most of them part of the former traditional elite, i.e. land owners or imams, life in communism overlaps with personal drama. ${ }^{14}$ The ethnic aspects of spirituality therefore fade into the background as the foreground is dominated by material survival under the communist regime. ${ }^{15}$

During the fifty years of communist policies, the Turks and Tatars moved away from their ethnic identities and had to adopt the only available attitude, subject nonetheless to censorship, that would allow them to express themselves to some extent as individuals and as a group, namely to act as a religious community of Islamic faith. The field research conducted at the time showed, as I pointed out in previous papers, that regardless of the degree of religiosity Islam remained a strong identity marker. The mosque, the community life organized around religious celebrations but also the family, particularly the elders, appear to be the core elements of language and faith transmission during communism. It is noteworthy that this very approach made possible the survival of cultural and social elements ${ }^{16}$ which are culturally and ethnically defined for both the Turks and the Tatars, a result of their belonging to the same Turkic world.

\section{The Post-Communism}

Xavier Bougarel (2003) argues that the creation of a new intellectual and technical elite in Muslim communities during communism was the prerequisite for the affirming of Balkan Muslims as political actors after the collapse of the Soviet bloc, typical of post-communism. In 1989-1990,

13 Interview with H. A., member of the Tatar community, 29 January 2013; Interview with O. E., member of the Tatar community, 29 January 2013; Interview with M. F., member of the Tatar community, 29 January 2013.

14 Interview with G. A., member of the Tatar community, 29 January 2013; Interview with S.M., member of the Tatar community, 30 January 2013.

15 See previous studies in Cupcea, 2013: 26.

16 The mosque and the family, along with the reunions for the two main Islamic celebrations, Kurban Bayram and Ramazan Bayram, for weddings, baptisms, funerals, were the core elements for the preservation of the sense of belonging to the religious and ethnic community during communism. 
following the dissolution of communist regimes, Muslim political parties and organizations were created in all the Balkan countries (Bougarel, 2003: 249). It should be noted that the Dobruja Turks and Tatars belong to the East Balkans region, i.e. Bulgaria, Greece and Romania; Muslims are only a minority in the total populations living in centralized states (Bougarel, 2005: 7). Under these circumstances, this particular minority opted for creating ethnic organizations and claiming ethnic minority status and the cultural rights derived from it (Bougarel, Clayer 2001:30).

As early as 1989, some representatives of the secular Dobruja Turk and Tatar generations formed during communism set up an organization to represent both communities, based on their shared Turko-Islamic identity component. As early as the last days of December 1989 Muslim Turkish Democratic Union of Romania was created. As a result of disagreement within the community, it was decided that the organization should split into two separate ones: The Union of the Ethnic Turkish Minority of Romania, which later took the name of The Turkish Democratic Union of Romania (TDUR), and the Democratic Union of Turco-Islamic Tatars of Romania (DUTITR), both organizations having as main declared goal the preservation and perpetuation of the cultural and traditional values of ethnic Turks and Tatars respectively.

\section{Conclusions. Overlapping identities: religious and ethnic layers}

After 1990 Muslim Turks and Tatars embarked on a process of identity rebuilding where belonging to a single religious community or to different ethnic communities - whether Turk, Tatar or Turko-Tatar - are choices backed by historical, cultural, symbolic, political or material reasons, hence the need for a two-tier analysis - (1) the official level or the level of the elite, and (2) the level of the community members. ${ }^{17}$

The religious identity, at least officially, therefore becomes to some extent incorporated into the ethnic identity. The reverberations of the official organization based on ethnic criteria reached the individual members of the two communities, who opt for separate ethnic identities, Turk or Tatar.

Despite these variations in identity and claims to specificity by each of the two ethnic groups, both the Turks and the Tatars acknowledge in their official and individual discourses the link between the two ethnic groups manifested as religious affinity, shared customs and belonging to the same Turkic world. These elements are also reflected in the public discourse of the Romanian majority population that refers to the two groups as Turko-Tatars. ${ }^{18}$ Most Turks and Tatars accept to be perceived and classified as one local ethnic category in their everyday lives but on a deeper level their identity discourse is far from being unified. ${ }^{19}$ To conclude, their social interaction with

17 The conclusion is based on a wider field research (semi-structured interviews, life histories) conducted in 2014 in rural and urban Turkish and Tatar communities in Constanța county (Romania).

18 Interview with S. T., member of the Turkish community, January 31, 2013; Interview with Te. B., member of the Tatar community, July 28, 2014; Interview with Ta. B., member of the Tatar community, July 28, 2014. 
the Romanian majority population determines the ethnic Turks and Tatars to accept rather easily the Turko-Tatar ethnic pattern in their everyday social experiences. It is in fact a pattern imposed by the general perception of the majority population, a construct of the Other and of historical, social and political facts, which has undergone many transformations since 1878 until today.

The rationales for this apparently unproblematic acceptance are two-fold. First, the acceptance is supported by historical and cultural facts, namely the shared Islamic faith which is portrayed as a fact in the present, with roots in the past. The Turks' and the Tatars' having the same Islamic religion while living in a Christian state defined the Other's - the state's or society's - perception of them as a homogenous Muslim community. In time, this shared feature along with the customs, values and principles derived from Islam determined the compounding of the two ethnonyms into one - Turko-Tatar - still widely used and accepted. However, this reflects only partially the current identity choices of the members of the two communities and, not least, it clashes with their representation as separate minorities.

Second, there is the sociological explanation, namely the phenomenon of mixed marriages that started in communism as part of the urbanization and industrialization processes and intensified in post-communism.

The present-day fact of mixed marriages reveals just how important the religious component is for the way the Turks and Tatars build their identities. In most cases, the marriage between a Turk and a Tatar does not challenge the ethnic perceptions of either Turks or Tatars because of the prominence of religion in their identity structure and, consequently, its prominence in lifecycle events $^{20}$. Therefore, in this context, their collective self-definition is that of a single Muslim religious community and implicitly of a Turko-Tatar community. ${ }^{21}$ The present-day fact of mixed marriages both shows the long-lasting historical implications of a shared faith and is an ongoing social trend that allows us a glimpse into the future of the two communities while reaffirming the prevalence of religious identity over ethnic identity for Dobruja Turks and Tatars.

Tatar community, October 14, 2013; Interview with E. E., member of the Turkish community, October 17, 2013; Interview with E. M., member of the Tatar community, May 22, 2014; Interview with M. A. M., member of the Turkish community, May 20, 2014. 


\section{References}

\section{Books}

Adanir, Fikret ,Farooqi (2002) Sureya, Ottomans and the Balkans: A Discussion of Historiography. Leiden: Brill Academic Publishers.

Florea, Elena (1975) Principiile politicii PCR in problema națională [PCR policy principles in the national question], București: Editura Politică.

Hanioğlu M. Șükrü ( 2001) Preparation for a Revolution, The Young Turks, 1902-1908, Oxford: Oxford University Press.

Ekrem, Mehmet Ali (1994) Din istoria turcilor dobrogeni [The History of Turks from Dobruja], Bucharest: Kriterion.

Fisher, Alan W.(1978) The Crimean Tatars, Stanford: Hoover Institution Press.

Ibram, Nuredin (1998) Comunitatea musulmană din Dobrogea: repere de viață spiritual, viață religioasă și învățământ în limba maternă [The Muslim Community in Dobruja: landmarks of spiritual and religious life and mother tongue education], Constanța: Ex Ponto.

*** (2011) Comunitatea musulmană din Dobrogea [The Muslim Community in Dobruja], Constanța: Ex Ponto.

Kırıml, Hakan (1996) National Movements and National Identity Among the Crimean Tatars 1905-1906, Leiden, New York, Köln: Brill.

Merdjanova, Ina (2013) Rediscovering the Umma. Muslims in the Balkans between Nationalism and Transnationalism, Oxford: Oxford University Press.

Popovic Alexandre (1986) L'Islam Balcanique. Les musulmans du sud-est européen dans la période postottomane, Berlin: Otto Hassarowitz Wiesbaden.

Maria Todorova (2004) Balkan Identities. Nation and Memory, London: Hurst\&Company, London.

Williams Brian Glyn (2001) The Crimean Tatars. The Diaspora Experience and Forging of a Nation; Leiden: Brill.

\section{Studies and articles}

Bougarel, Xavier (2003) "Islam and Politics in the Post-Communist Balkans (1990-2000)", in Keridis, Dimitris; Perry, Charles (eds.) New Approaches to Balkan Studies, Dules: Brassey's, 245-360.

*** (2005) “The role of Balkan Muslims in building a European Islam”, European Policy Center Issue Paper, 43 [online], https://hal.inria.fr/file/index/docid/220374/filename/The_Role_of_Balkan_Muslims_ in_European_Islam.pdf, accessed on 01.03.2016.

Bougarel, Xavier; Clayer Nathalie (2001) “Introduction", in Bougarel, Xavier; Clayer Nathalie (eds.) Le nouvel islam, balcanique. Les musulmans, acteurs du post-communisme (1990-2000), Paris: Maisonnneuve\&Larose. 11-75.

Brubaker, Rogers (1995) "National Minorities, Nationalizing States and External National Homelands in the New Europe”, Daedalus 124 (2):107-132.

Cupcea Adriana (2013) “Construcția identitară la comunitățile turcă și tătară din Dobrogea. Studii de atelier. Cercetarea Minorităților Naționale din România [Identity Construction in the Turkish and Tatar Communities in Dobruja. Working Papers in Romanian Minority Studies]", The Romanian Institute for Research on National Minorities, 49 [online], http://www.ispmn.gov.ro/uploads/WP49-11-10. pdf, accessed on 15.03.2016. 
Clayer, Nathalie (2004/ 2005) "Les Musulmans des Balkans ou l'islam de «l'autre Europe»", Le courrier des pays de l'Est, 1045: 16-27.

Dulciu, Dan Toma (2009) "Condiția juridică a musulmanilor în țările membre ale Uniunii Europene. Reglementările comunitare și legislația românească. Studiu comparativ [The legal status of Muslims in European Union countries . Community regulations and Romanian law . comparative study]", Dionysiana, 8 (1).

Constantin Iordachi (2002) "Citizenship, Nation and State-Building: The Integration of Northern Dobrogea into Romania (1878-1913) ”, The Carl Beck Papers in Russian\& East European Studies, 1607.

Jovanović, Vladan (2015), "Land Reform and Serbian Colonization. Belgade’s Problems in Interwar Kosovo and Macedonia”, East Central Europe, 42 (1): 87-103.

Köksal, Yonka (2006) "Minority Policies in Bulgaria and Turkey: The Struggle to Define a Nation", South East European and Black Studies, 6 (4): 501-521.

Iordachi, Constantin (2002) "La Californie des Roumains. L'intégration de la Dobroudja du Nord à la Roumanie, 1878-1913", Balkanologie, 6 (1-2): 167-197.

de Jong, Frederik (1986) “The Turks and Tatars in Romania: material relative to their history and notes on their present-day condition", Turcica. Revue des études turques, 18: 165-189.

Oberländer-Târnoveanu, Ernest - Volker, Adam (2005) “Tătarii din România. Schiță istorică - Secolele XIII-XX [Tatars in Romania. A Historical Sketch]”, in: Andreescu, Gabriel (ed.) Tătarii din România - teme identitare. Tatars in Romania - Problems of Identity, Bucharest: Centrul pentru Drepturile Omului Apador-CH [ The Centre for Human Rights Apador-CH]: 27-57.

Omer, Metin (2014) "Mesageri de bună conviețuire: Evoluția presei turcești din România (1888-1989) [Messengers of conviviality: The Evolution of Turkish Media in Romania (1888-1989)]", Asociația Națională a Tinerilor Istorici din Moldova. Revistă de istorie [National Association of Young Historians of Moldova . Magazine of History], 11: 247-248.

Özgür Baklacioğlu, Nurcan (2015) "Between neo-Ottomanist kin policy in the Balknas and Transnational Kin economics in the EU”, Journal of Ethnopolitics and Minority Issues in Europe, 14 (3): 47-72.

Poulton, Hugh (1997) “Turkey as Kin-State: Turkish Foreign Policy towards Turkish and Muslim Communities in the Balkans", in: Hugh Poulton, Suha Taji - Farouki (eds.) Muslim Identity and the Balkan State, London: Hurst, 194-214.

Poulton Hugh (2000) “The Muslim Experience in the Balkan States. 1919-1991", Nationalities Papers, 28 (1): 47-66.

\section{Interviews:}

Interview with H. A., member of the Tatar community, 29 January 2013;

Interview with H. N., member of the Tatar community, October 14, 2013;

Interview with E. E., member of the Turkish community, October 17, 2013;

Interview with E. M., member of the Tatar community, May 22, 2014.

Interview with G. A., member of the Tatar community, 29 January 2013;

Interview with M. A. M., member of the Turkish community, May 20, 2014.

Interview with M. F., member of the Tatar community, 29 January 2013;

Interview with N. U., member of the Tatar community, September 16, 2013;

Interview with N. U., member of the Tatar community, September 16, 2013;

Interview with O. E., member of the Tatar community, 29 January 2013; 
Interview with O. F., May 22, 2014, member of the Turkish community.

Interview with S.M., member of the Tatar community, 30 January 2013;

Interview with S. T., member of the Turkish community, January 31, 2013;

Interview with Te. B., member of the Tatar community, July 28, 2014;

Interview with Ta. B., member of the Tatar community, July 28, 2014. 